\title{
IMPACTS OF TOURISM ACTIVITIES ON ECONOMY OF KAZAKHSTAN
}

\author{
Ruslan BAIBURIEV \\ Al-Farabi Kazakh National University, Department of Geography and Tourism \\ 050040 Almaty, al-Farabi Ave. 71, Kazakhstan, e-mail: skaut2ever@gmail.com
}

\section{Lorant DAVID*}

Eötvös Loránd University, Savaria Department of Business Economics HU-970o Szombathely, Károlyi Gáspár Sq. 4., Hungary, e-mail: dr.david.lorant@gmail.com

\section{Sholpan ABDREYEVA}

Al-Farabi Kazakh National University, Department of Geography and Tourism 050040 Almaty, al-Farabi Ave. 71, Kazakhstan, e-mail: sholpan.o07@mail.ru

\author{
Aiman ZHAKUPOVA \\ Al-Farabi Kazakh National University, Department of Geography and Tourism \\ 050040 Almaty, al-Farabi Ave. 71, Kazakhstan, e-mail: aiman.zhakupova15@gmail.com
}

\author{
Alexandr ARTEMYEV \\ Al-Farabi Kazakh National University, Department of Geography and Tourism \\ 050040 Almaty, al-Farabi Ave. 71, Kazakhstan, e-mail: Alexandr.Artemyev@kaznu.kz
}

Citation: BAIBURIEV, R., DAVID, L., ABDREYEVA, S., ZHAKUPOVA, A. \& ARTEMYEV A. (2018). IMPACTS OF TOURISM ACTIVITIES ON ECONOMY OF KAZAKHSTAN. GeoJournal of Tourism and Geosites, 22(2), 480-488. https://doi.org/10.30892/gtg.22217-304

\begin{abstract}
Kazakhstan is an economically stable country in Central Asia, which recently began to pay close attention to the development of tourism industry. It is fact that, tourism is not a major component of country's economy, as evidence, tourism industry GDP in Kazakhstan is \$3.08 billion or 1.6 percent of total GDP. The combination of direct and indirect influence of the tourist-spending scheme determines the impact on the local economy. Usually not all the income received in every cycle of tourists' expenses is spent. The more the share of income spent within the region, the greater the multiplier effect. The ability to keep a travel in the region depends on the economic isolation of the area and the independence of the local economy. If the local economy is able to produce goods and services that are in demand among tourists, then the multiplier effect will be very significant. Based on the initial data and assumptions made, it is possible to calculate the magnitude of the indirect impact of tourism on the economy of the country and obtain a multiplicative effect of tourism. The multiplicative effect of tourism, calculated on this expression, will be of an evaluation nature, so it is advisable to use an expert approach when justifying a number of indicators included in the formula. The above methodological approaches to determine the multiplier effect and aggregate income from tourism are applicable to the conditions and standards of statistical reporting and information throughout the country.
\end{abstract}

\footnotetext{
* Corresponding author
} 
Impacts of Tourism Activities on Economy of Kazakhstan

Key words: Kazakhstan tourism, economic impacts, multiplier effect, investment

\section{INTRODUCTION}

Kazakhstan is an economically stable country in Central Asia, which recently began to pay close attention to the development of tourism industry. It is fact that, tourism is not a major component of country's economy, as evidence, tourism industry GDP in Kazakhstan is $\$ 3.08$ billion or 1.6 percent of total GDP (Travel and Tourism Competitiveness Report 2017). In this regard, we observe a rise of scientific interest in context of exploring opportunities, identifying indicators of the impact of tourism development on the economy of the country, and assessing the prospects for its development according of analyzing the multiplier effect. The combination of direct and indirect influence of the tourist-spending scheme determines the impact on the local economy. Usually not all the income received in every cycle of tourists' expenses is spent. Some part of it is postponed, and the other is spent outside the region. The more the share of income spent within the region, the greater the multiplier effect. The ability to keep a travel in the region depends on the economic isolation of the area and the independence of the local economy. If the local economy is able to produce goods and services that are in demand among tourists, then the multiplier effect will be very significant. Tourism has a significant impact on economy and social development of the region, contributing to the flow of currency, creating new jobs, improving infrastructure, etc. The successful development of local tourism is associated with a clear understanding of its economic significance for the country's economy, determined by direct and indirect influence. The direct influence of tourism, with some degree of reliability, is taken into account in the framework of the current national accounts of Kazakhstan. The indirect impact of tourism for the national economy of Kazakhstan has not yet taken into account, but the relevance of such accounting is undeniable (Nurgaliyev, 2013). The modern economic theory of the multiplicative effect acknowledges us to analyze a methodological tool for accounting tourism influence in the form of a tourist multiplier.

The economic contribution of tourism is felt in direct, indirect and induced routes (figure 1). These impacts and the structure of the tourism sector establish the sectors economic impact on a country. Direct economic impacts are created when commodities like the following are realized: accommodation and entertainment, food and beverages services, retail opportunities (Norjanah et al., 2014). Residents, visitors, businesses - all influence have direct tourism impacts through their spending or economic activities of various levels of governments near the touris m area (Goeldner et al, 2009). In contrast, indirect economic impacts from tourism industry realized by investment spending that surrounding a tourism, offering from private and governmental interests. This investment may explicitly be unrelated with tourism, but benefits for the tourist and local stakeholders all the same. Indirect economic impacts (supply chain, investment, and government collective) account for $51.7 \%$ of the total GDP contribution from travel and tourism in 2016 (Turner, 2017). Induced impacts is representing the wider contribution of tourism through the expenditures of those who are directly or indirectly employed by the tourism sector (Lemma, 2014).

The indirect impact of tourism is much broader in its socio-economic nature; also, its cumulative impact far overtakes the direct economic and social effect. The reason for this is the effect of the multiplier, when the chain of "expenses - incomes" through tourism stimulates the development of economy and other related industries associated with it. If more tourists spend money at the place of the stay; the greater the 
amount of transaction "costs - income than the higher the indirect (multiplicative) impact of tourism. In addition, the indirect income from tourism for the region came from that part of the money spent, that do not go beyond it. Estimate indirect revenues from tourism, allows the practice for controlling the multiplier to compare the contribution of industries with the development of the region's economy.

\begin{tabular}{|c|c|c|c|}
\hline & Sector & Impact & Effect \\
\hline \multirow{5}{*}{$\begin{array}{l}\text { Visitor } \\
\text { Spending }\end{array}$} & Transportation & \multirow{4}{*}{$\begin{array}{c}\text { Direct } \\
\text { Indirect }\end{array}$} & \multirow{2}{*}{ Production } \\
\hline & Accommodations & & \\
\hline & Food and Beverage & & \multirow{2}{*}{ Jobs } \\
\hline & Entertainment & & \\
\hline & $\begin{array}{r}\text { Recreation } \\
\text { Retail }\end{array}$ & Induced & Taxes \\
\hline
\end{tabular}

Figure 1. Tourism economic impact

\section{THE MULTIPLICATIVE EFFECT IN TOURISM}

There are many methods for calculating the multiplicative effect in tourism. They are most widely used in the United States and European Union countries, and often used to assess the overall economic effect of tourism for a

specific territory and to justify strategic decisions in the field of tourism and tourism infrastructure (Gulyaev, 2003).

Currently, there are a number of models and methods for calculating a generalized multiplier effect for various sectors of the economy, proposed in the works of foreign scientists like Keynes J.M. («The general theory and after part 1 preparation», etc.), Samuelson P. («Economics», etc.), Morishima M. («The economic theory of modern society»), Pagoso C.M. («Principles of economics») and others.

Scientists recognize the fact that the impact of the multiplier effect of tourism, in comparison with the effect of other activities, is the most significant, since it is the initial catalyst for the development of many industries (Rutter, 2001; Samuelson, 1989).

One of the most traditional areas of economic research in tourism is the assessment of its contribution to the development of the economy of individual countries and tourist destinations. These issues are dealt with the scientific works of Frechtling (1999), Jones (2007), Spurr and other scientists. Over the past forty years, many studies have been carried out related to multiplicative effects in tourism using input-output models (IOM). These are the works of Archer, 1977; Fletcher, 1996 and Crompton, 2001.

In recent years, the paradigm of studying the economic impact of tourism as a result of using general equilibrium models instead of IOM models has undergone a change. General equilibrium computation models can be adapted to simulate alternative conditions, such as flexible or fixed prices, alternative exchange rate changes, differences in the degree of factor mobility, and various types of competition. The questions of general equilibrium modeling for the estimation of economic consequences were considered in the works of Adams and Parmenter, 1995; Dwyer, 2003. The economic consequences of financial crises in the sphere of tourism were studied in the works of Blake, 2003; Pambudi, 2009. The work of Blake and Arbache, 2008; Coxhead, 2008 and others are devoted to the impact of tourism on income distribution and poverty reduction. Recently, this issue involved concentrated attention in the Commonwealth of Independent States. The scientific researches in the field of tourism multiplier are reflected in scientific works of Kvartalnov, 2005; Gulyaev, 2003; Morozov, 2014; Papiryan, 2000. The multiplicative effect of tourism manifested by chain income, 
received from one tourist, exceeds the amount of money spent by a consumer at the place of the stay for the purchase of services and goods.

Tourism has an impact for the economy in almost all aspects of the fundamental definition of this area of society. In economic terms, tourism is considered:

1) A particular set of social relations in the sphere of production, exchange and distribution of products;

2) A part of the national economy, including particular types of manufacturing industry and economic activity;

3) Economic science that studies tourism as a branch of the economy of the country or region (tourism economy);

4) Social science, studying behavior in the spheres of production of the tourist product, its consumption, distribution and exchange. Economists analyze the processes occurring in these spheres, predict their consequences for individuals, organizations and society as a whole;

5) Modern economic theory that considers the behavior of people as economic entities at all levels of the tourist economic system in the processes of production, distribution, exchange and consumption of tourist services in order to meet human needs with limited resources of the family, firm and society as a whole.

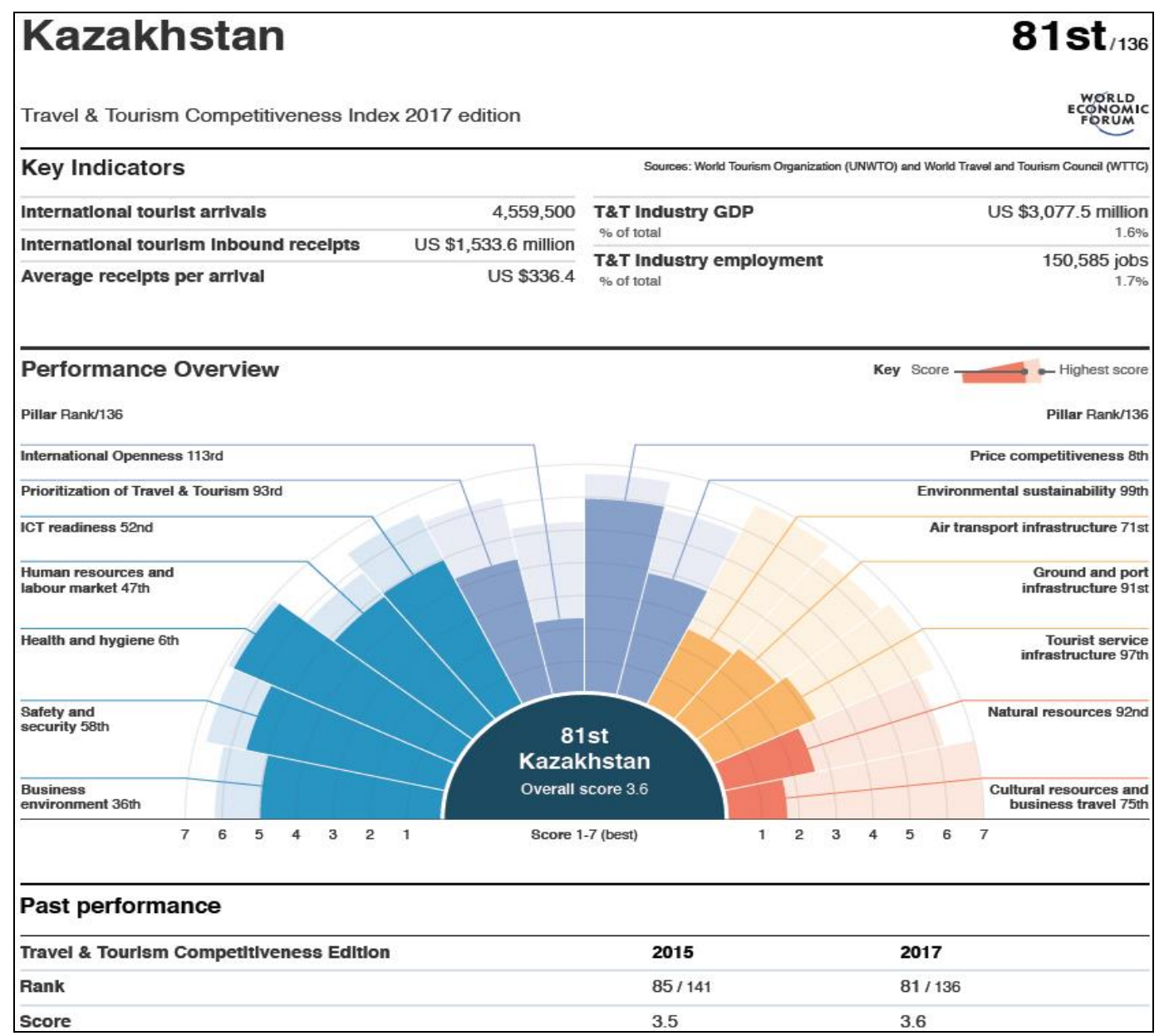

Figure 2. Tourism and travel competitiveness index 2017 (Source: Schwab et al., 2017) 
The economic space of the hospitality and tourism sphere covers most of the world economy. Many developed countries regard tourism and services as a priority for their economic development, because this sector is very attractive in terms of investment. Kazakhstan occupies 81st place in the rating of tourist attraction assigning to the data of the World Economic Forum (figure 2). Economic indicators of the development of the tourism industry in Kazakhstan demonstrate an annual growth for the last five years; it shows a leisurely but steady pace. Individual indicators of economic activity are characterized by high results, such as health and hygiene, price competitiveness.

To assess the impact of tourists' expenditures on income, employment and imports, scientists expanded altered models for calculating the multiplier effect. One such models for affecting the multiplier effect of tourism was created by Brian H. Archer and Christine B. Owen (Archer and Owen, 1971), which formula looks like this:

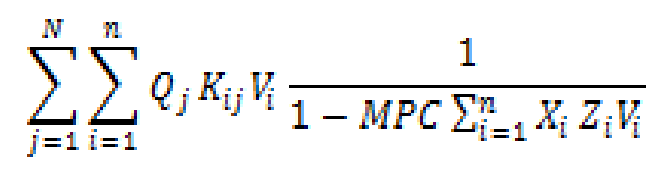

where: first part formula is direct and indirect income generated

$\mathrm{j}=$ each category of tourists, $\mathrm{J}=1$ to $\mathrm{N}$;

$\mathrm{i}=$ each type of business establishment, $\mathrm{i}=1$ to $\mathrm{n}$;

$\mathrm{Q}_{\mathrm{j}}=$ the proportion of total tourist expenditure spent by the $\mathrm{j}^{\text {th }}$ type of tourist; business;

$\mathrm{K}_{\mathrm{ji}}=$ the proportion of expenditure by the $\mathrm{j}^{\text {th }}$ type of tourist in the $\mathrm{i}^{\text {th }}$ category of business;

$\mathrm{V}_{\mathrm{i}}=$ direct and indirect income generated by unit of expenditure by the $\mathrm{i}^{\text {th }}$ type of

Second part includes the additional income generated by re-spending of factor earnings by resident population;

$\mathrm{X}_{\mathrm{i}}=$ the proportion of total consumer expenditure by the residents of the area in the $\mathrm{i}^{\text {th }}$ type of business;

$\mathrm{Z}_{\mathrm{i}}=$ the proportion of $\mathrm{X}_{\mathrm{i}}$ which take place within the area;

$\mathrm{MPC}=$ the marginal propensity to consume.

\section{RESULTS}

We have attempted to calculate the multiplicative effect of tourism on a national scale, based on the official statistical information of the Committee on Statistics of the Ministry of National Economy of the Republic of Kazakhstan. Based on the initial data and accepted assumptions, it is possible to calculate the magnitude of the indirect impact of tourism on the economy of the country - the multiplicative effect of tourism (Table 1).

Table 1. Expenses of entry visitors by object of expenditure in the territories of Kazakhstan (Data source: Ministry of national economy of the Republic of Kazakhstan, Committee on Statistics January 1, 2018)

\begin{tabular}{|c|c|c|c|c|c|}
\hline \multicolumn{7}{|c|}{ Amount of money spent, Thsd KZT } \\
\hline $\begin{array}{c}\text { Accom- } \\
\text { modations }\end{array}$ & $\begin{array}{c}\text { Transport } \\
\text { services }\end{array}$ & $\begin{array}{c}\text { Services of travel } \\
\text { agencies and operators }\end{array}$ & $\begin{array}{c}\text { Food and } \\
\text { beverage }\end{array}$ & $\begin{array}{c}\text { Recreational, cultural } \\
\text { and sport events }\end{array}$ & $\begin{array}{c}\text { Other } \\
\text { expenses }\end{array}$ \\
\hline 141204,1 & 49971,2 & 2355,9 & 157361,2 & 10781,9 & 2014,7 \\
\hline
\end{tabular}


Taking into account the dynamics of the turnover of tourist costs within the tourist multiplier, the calculation of the indirect influence of tourism in a generalized form will look like this (Morozov, 2014):

$$
\begin{gathered}
\mathrm{K}=\mathrm{P}+\mathrm{P} * \mathrm{MPC}+\mathrm{P} * \mathrm{MPC}_{2}+\mathrm{P} * \mathrm{MPC}_{3}+\ldots+\mathrm{P} * \mathrm{MPC}_{\mathrm{n}} \\
\mathrm{T}=\frac{p}{(1-\mathrm{MPC})} \\
\mathrm{k}=\frac{1}{(1-\mathrm{MPC})}=\frac{1}{\mathrm{MPA}}
\end{gathered}
$$

$\mathrm{K}$ - circulation coefficient of multiplier;

MPC - marginal propensity to consume;

MPA - marginal propensity to accumulate;

$\mathrm{P}=$ const;

$\mathrm{T}-$ producing of tourist products (services).

$\mathrm{k}$ - tourism multiplier.

The use of such models of calculation assumes the existence of equilibrium demand-consumption in the system of economic turnover of the country and the invariable parameter of investments for 2013-2016 (Table 2, 3). Tourism investment in 2016 was KZT 575.4 bn (in USD $1.7 \mathrm{bn}$ ), as a percentage $5.4 \%$ of total investment. According to the forecast, it will raised by $4.0 \%$ in 2017 (figure 3).

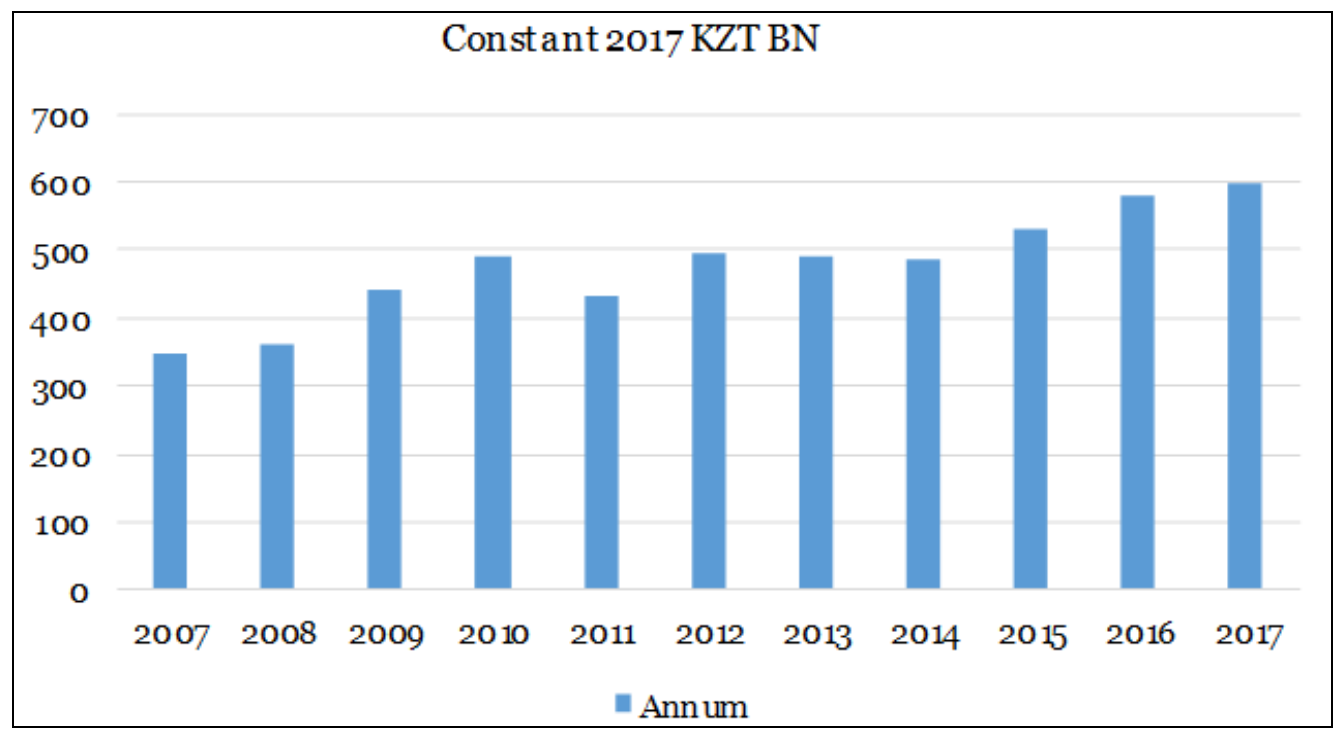

Figure 3. Capital investment in tourism industry (Source: Turner, 2017)

As an investments in the economy of Kazakhstan we are considering the aggregate expenditures of tourists and excursionists $(\mathrm{P}=330.7$ USD (exchange rate as of 04/o6/2018). In the given accounting period (2018), tourists' expenses assumed unchanged, as was the marginal propensity to consume. 
Table 2. The level of nominal income and expenses in Kazakhstan in 2013 - 2017 years (Data source: Ministry of national economy of the Republic of Kazakhstan, Committee on Statistics, 2018

\begin{tabular}{|c|c|c|}
\hline Years & Income level*, KZT & Expense level, KZT \\
\hline 2013 & 550075 & 386655 \\
\hline 2014 & 601541 & 411260 \\
\hline 2015 & 647091 & 426912 \\
\hline 2016 & 719501 & 462002 \\
\hline 2017 & 746477 & 555831 \\
\hline \multicolumn{2}{|c|}{ * Data taking into account with the adjustment of monetary indicators (social transfers, material }
\end{tabular}
assistance from relatives, alimony and other incomes deducted from the total indicator)

Table 3. Marginal propensity to consume (MPC) in 2013 - 2017 years

\begin{tabular}{|c|c|}
\hline Years & Marginal propensity to consume (MPC), \% \\
\hline 2013 & 70 \\
\hline 2014 & 68 \\
\hline 2015 & 65 \\
\hline 2016 & 64 \\
\hline 2017 & 74 \\
\hline
\end{tabular}

The average marginal propensity to consume in 2013 was $70 \%$, in $2014-68 \%$, in $2015-65 \%$, and in $2016-64 \%$. It should be noted that the Kazakh government in 2015 agreed to a policy of inflation targeting, which may contributed to this calculation. Table 3 shows the tendency to consumption decreases last 4 years, however, in 2017, the indicators of the marginal propensity to consume of the population shows a recovery for the last five years, this indicator is 74 percent. Probably, this growth can be attributed to the improvement of the social and economic situation in the country; the rise of oil prices for the last accounting year also plays a role, political reforms were carried out, etc. Using the calculation models (Morozov, 2014), we obtained the following indicators:

$$
\mathrm{T}=\frac{\mathrm{p}}{(1-\mathrm{MPC})}=\frac{330_{2} 7}{(1-0,74)}=1271,92 \mathrm{USD}
$$

(2017 year)

Direct revenues from producing of tourist products and services for 2013 in our country amounted to 1121 USD, and so it can be determined for each year (2014 year 1051 USD, 2015 year - 961 USD, 2016 year - 934 USD, 2017 - 1272 USD).

The formula for calculating geometric parameters for identifying circulation coefficient of multiplier (Kvartalnov, 2005) and the amount of income growth at each turnover in 2017 year:

$$
\begin{array}{r}
\mathrm{K}=330.7+330.7 \times 0,74+330.7 \times 0,74^{2}+330.7 \times 0,74^{3}+330.7 \times 0,74^{4}+330.7 \times \\
0,74^{5}+\ldots+330.7 \times 0,74^{15}=330.7+244.7+181.1+134+99.2+\ldots+0,75 \approx 1271,92
\end{array}
$$

Define the number of the coefficient of the tourist multiplier:

$$
\mathrm{k}=\frac{1}{(1-\mathrm{MPC})}=\frac{1}{\mathrm{MPA}}=\frac{1}{(1-0,74)}=3,84
$$

In our case study, with a multiplication factor of $\mathrm{K}=3.84$, the money spending of each tourist and excursion in the rate of 330,7 USD generate an additional revenue in the rate of 1271,9 USD in the Kazakhstan's economy, making more than 17 turnover transactions. According to the World Tourism and Travel Council, the share of the 
tourism industry in the country's total GDP is 1.6 percent with a total of $\$ 3,077$ million USD, which recruits 150,585 people, who able to work of country's population. The totally influence of multiplicative effect from tourism for the economy of Kazakhstan is about 900 million USD, and an average 2 million USD from them, is returned directly to tourism sphere from the country's budget.

\section{CONCLUSION}

The combination of direct and indirect influence of the tourist-spending scheme determines the impact on the local economy. Usually not all the income received in every cycle of tourists' expenses is spent. Some part of it is postponed, and the other is spent outside the region. The more the share of income spent within the region, the greater the multiplier effect. The ability to keep a travel in the region depends on the economic isolation of the area and the independence of the local economy. If the local economy is able to produce goods and services that are in demand among tourists, then the multiplier effect will be very significant. The more goods imported from other regions, the less the multiplier effect. The Kazakhstan has plenty to offer travelers, from tours designed to highlight the natural beauty of its mountains, lakes and deserts to more offbeat itineraries, including space tourism at the Baikonur cosmodrome and a visit to a Soviet-era gulag prison camp. Despite all the options, the tourism industry in Kazakhstan is hugely under-developed. Limitations associated with an unsustainable supply may become a limiting factor in the number of offers and the quality of goods and services, which is actively affected by the increase in tourism development costs. As we know, if excessive demand is not satisfied by local production, additional tou rist spending creates inflation and missing products and services are imported from other places. Besides, the size of the multiplier is reduced.

In addition to the multiplier effect, there are accompanying economic phenomena. The growing costs of tourists cause the need for additional labor, which is expressed by the employment rate. As the tourist region expands, its infrastructure is improved, new buildings and structures are being built. Therefore, you can calculate the income ratio. Let us consider these coefficients in more detail. A detailed analysis of the multipliers is carried out to analyze the effectiveness of public or private sector investments in tourism projects at national and regional levels, to check the relative magnitudes of the impact of different types of tourism and the impact of tourism in comparison with other sectors of the economy. Based on the initial data and assumptions made, it is possible to calculate the magnitude of the indirect impact of tourism on the economy of the country and obtain a multiplicative effect of tourism. The multiplicative effect of tourism, calculated on this expression, will be of an evaluation nature, so it is advisable to use an expert approach when justifying a number of indicators included in the formula. The above methodological approaches to determine the multiplier effect and aggregate income from tourism are applicable to the conditions and standards of statistical reporting and information throughout the country.

\section{REFERENCES}

Adams, P.D. and Parmenter, B.R. (1995). An applied general equilibrium analysis of the economic effects of tourism in a quite small, quite open economy. Applied Economics, vol. 27 (10), p. 985-994.

Archer, B., \& Fletcher, J. (1996). The Economic Impact of Tourism in the Seychelles. Annals of Tourism Research, vol. 23, 1: p. 32-47. 
Archer B., H. \& Owen C., B. (1971). Towards a tourist regional multiplier. Regional Studies, vol. 5, issue 4, p. 89-294.

Blake, A.T. \& Sinclair M.T. (2003). Tourism crisis management: US response to September 11. Annals of Tourism Research, vol. 30 (4), p. 813-32.

Blake, A., Arbache, J.S., Sinclair M.T. \& Teles, V. (2008). Tourism and Poverty Relief. Annals of Tourism Research, Vol. 35, No. 1, p. 107-126

Crompton, J.L., Lee S., \& Shuster T. (2001). A Guide for Undertaking Economic Impact Studies: The Springfest Festival. Journal of Travel Research, vol. 40 (1): p. 79-87.

Dwyer, L. \& Kim C.W. (2003). Destination Competitiveness: a Model and Indicators. Current Issues in Tourism, Vol. 6, No. 5, p. 369-413.

Frechtling, D. (1999). The tourism satellite account: foundations, progress and issues. Tourism Management vol. 20, P. 163-170.

Goeldner, C.R., Ritchie, J.B. (2009). Tourism Principles, Practices, Philosophies, $11^{\text {th }}$ Edition. John Wiley \& Sons. New Jersey, p. 657.

Gulyaev V.G. (2003). Tourism: the economy and social development. M.: Finance and Statistics, p. 69. (in Russ.).

Jones, C., \& Munday M. (2007). Exploring the Environmental Consequences of Tourism: A Satellite Account Approach, Journal of Travel Research, vol. 46; p. 164.

Kvartalnov V.A. (2005). Tourism management. Tourism Economics. M.: Finance and Statistics, p. 80-85. (in Russ.).

Lemma, A.F. (2014). Tourism impacts. Evidence of impacts on employment, gender, income. EPS PEAKS, London, P. 2-3.

Morozov M.A., Morozova N.S., Karpova G.A., \& Khoreva L.V. (2014). The economy of tourism. M.: Federal Agency for Tourism, p. 320 (in Russ.).

Nurgaliyev, A.S. (2013). The multiplicative effect of tourism in the region. KazKKA Habarshy, vol. 2 (63). Kokshetau, P. 190-197. (in Russ.).

Norjanah, M.B., Jaafar M. \& Mohamad D. (2014). Perceptions of Local Communities on the Economic Impacts of Tourism Development in Langkawi, Malaysia. SHS Web of Conferences. Vol. 12, p. 1-10.

Pambudi, D., McCaughey N., \& Smyth R. (2009). Computable General Equilibrium Estimates of the Impact of the Bali Bombing on the Indonesian Economy. Tourism Management, p. 30.

Papiryan G.A. (2000). International economic relations. Economy of Tourism. M.: Finance and Statistics, p. 208. (In Russ.).

Ruetter H. (2001). Wirtschaftsfaktor Tourismus. In: Wolkswirtschaftin der Schweiz. Bern, p. $125-132$.

Samuelson P. (1989). Economics, $13^{\text {th }}$ Edition. McGraw Hill. New York, p. 837.

Schwab K., Martin C., Samans R., Moavenzadeh J., \& Drzeniek-Hanouz M. (2017). The Travel \& Tourism Competitiveness Report 2017. Geneva: World Economic Forum, p. 387.

Turner R., (2017). Travel and Tourism: Economic Impact 2017 Kazakhstan. London: WTO, p. 1-24.

Turner, R. (2017). Travel and Tourism: Economic Impact 2017 World. London: WTO, p. 20.

Wattanakuljarus, A. \& Coxhead, I. (2008). Is tourism-based development good for the poor? A general equilibrium analysis for Thailand. Journal of Policy Modeling, vol. 30 (6), P. 929-955.

*** The official statistical information. The tourism bulletin for 2018. Ministry of national economy of the Republic of Kazakhstan Committee on Statistics. [Electron. resource]. http://stat.gov.kz/faces/ wcnavexternal Id/ accessed 12.03.2018

Submitted:

20.12.2017
Revised:

15.06.2018
Accepted and published online 18.06.2018 